HELMINTHOLOGIA, 52, 3: 261 - 269, 2015

\title{
Different changes of soil nematode communities in replant and continuous-planting peach orchards and their indicative value for peach replant problem
}

\author{
X. Y. LI', Q. Z. LIU1*, Y. Z. WANG ${ }^{2}$, H. Y. SUN², C. Q. BAI', E. E. LEWIS ${ }^{3}$
}

'Department of Entomology, College of Agriculture and Biotechnology, China Agricultural University, Beijing, China, *E-mail: Iqzzyx163@163.com; 'Institute of Pomology and Forestry, Beijing Academy of Agriculture and Forestry Sciences, Beijing, China; ${ }^{3}$ Department of Entomology \& Nematology, University of California-Davis, Davis, CA, United States

\section{Article info}

Received January 17, 2015 Accepted March 25, 2015

\begin{abstract}
Summary
Long-term changes of soil nematode diversity and distribution patterns in replant peach orchard (RPO) and continuous-planting peach orchard (CPPO) were assessed to evaluate different effects on nematode community and function by RPO and CPPO, in relation to peach replant problem from the point of soil fauna. Observations were conducted on a silt loam soil, and soil sampling was performed four times through the growing season of peach trees in the period from 2006 to 2008 in Pinggu, Beijing. The result showed that RPO differed from CPPO by its higher abundance of plant feeding nematodes but lower abundance of bacterivore nematodes, as well as significantly higher values of plant parasite index but lower nematode biodiversity. Obviously, the absolute abundance of Paratylenchus in RPO was higher than that in CPPO, which could be a key factor for the peach replant problems from the part of soil nematode. Nematode function indices and weighted nematode fauna profile analysis were no significantly different in the two peach ecosystems, but they represented an indication of high disturbance, N-enriched, bacterial decomposition pathway.

Keywords: Amygdalus persica L.; replant problem; nematode biodiversity; nematode function; plant parasitic index; Paratylenchus spp.
\end{abstract}

\section{Introduction}

Peach [Prunus persica (L.) Batsch] originally from China, is one of the important tree fruit crops in the world. China leads the world in peach production, accounting for approximately one-third of the world's annual total yield, nearly 8.33 million tons of peaches, is harvested from more than 782,000 hectares every year according to Food and Agriculture Organization (FAO). Nevertheless, replant problem has reduced the productivity and sustainability of peach orchards and also played important roles in the management of forest and fruit trees all worldwide (Nickle, 1984).

The common symptoms of peach replant problem are expressed as stunted growth, low productivity and a decline in tree vigor, all of which could shorten the economic viability of a peach orchard. There are conflicting reports in the literature concerning the complex etiology of this problem, and the replant problem likely results from a combination of diseases and disorders of complex etiologies, and cannot be attributed to any one factor (Derrick \& Timmer,
2000). The failure of the replanted trees has been linked to the activity of insects and nematodes as well as to the effect of poor plant nutrition, toxic agents, and spray residues (Koch, 1955). As the most abundant metazoans in soil, nematodes are one of the most numerically important components of the soil fauna. They play a central role in the detritus food web, influencing not only soil decomposition and conditions, but also nutrient recycling (Yeates, 2003). They are also food- and host-specific, and sensitive to anthropogenic disturbance and agricultural management activities (Ferris et al., 1999; Thornton \& Matlack, 2002). Changing soil conditions have direct and indirect effects on soil nematode populations and community structure, which makes these communities ideal as indicators of changes in the soil environment and the stability of soil ecological systems. (Bongers \& Ferris, 1999; Ferris et al., 2001; Neher, 2001). Indeed, considerable evidence supports the use of indicator guilds/nematode fauna analysis as a useful tool in assessing the structure, function, and probably the resilience of soil ecosystems (Ferris et al., 1999; Ritz \& Trudgill, 1999). 
Very little information is available about soil nematode communities in peach orchards that are either replanted (RPO) or have continuous-planting (CPPO). Aiming to find the main factors of replant problem from the point of soil animal ecosystem, mainly through biodiversity and structure of the soil nematode community as well as soil food web structure, we conducted a study in each of the two ecosystem types (RPO where trees were replaced at the beginning of the study, and CPPO where the trees remained throughout the study) for three years.

The objectives of this study were to determine: (1) how nematode community composition and faunal structure differ between the two ecosystems; (2) how biodiversity and ecosystem functions differ between the two peach orchard ecosystems; and (3) which genera in the soil nematode community play a central role in each of the systems. We hypothesize that the different effects of RPO and CPPO on nematode communities have some reflection of peach replant problem from the point of soil fauna.

\section{Material and Methods}

\section{Site descriptions}

We selected two trial sites each of RPO and CPPO in the Ping Gu district $\left(40^{\circ} 02^{\prime}-40^{\circ} 22^{\prime} \mathrm{N}, 116^{\circ} 55^{\prime}-117^{\circ} 24^{\prime} \mathrm{E}\right)$. This area is in the northeast of Beijing, China, where the most intensive peach cultivation systems are located. The average annual temperatures is about $11.5^{\circ} \mathrm{C}$, and the average annual precipitation is $644 \mathrm{~mm}$. The soil at this study site is classified as Arenosols (AR) according to the World Reference Base (WRB) (IUSS Working Group WRB, 2006).

The peach trees in RPO (0.8 hectares) had grown for 12 years in the first plantation since 1994, and then followed by the second plantation for 3 years, while those in CPPO (1.1 hectares) have
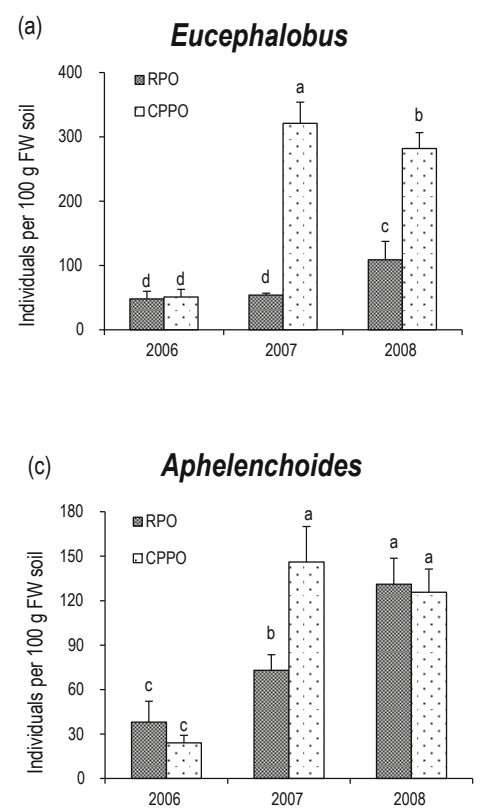

been growing constantly in this site for 15 years since 1994. Previous to 1994, the area used for the study had been cropped with wheat with standard fertilization and pest management. In the both two orchards, organic fertilizer (45 kg/tree), together with NPK compound fertilizer $(0.40 \mathrm{~kg} / \mathrm{tree})$ was applied in early September, and lime sulphur was used for pest control when necessary.

\section{Extraction and Identification}

Three sub-plots (144 $\mathrm{m}^{2}$ ) were arranged in a randomized complete block design in each orchard. Soil samples were collected in April (flower bud period, $1^{\text {st }}$ growth peak period), June (young fruit growing period, $2^{\text {nd }}$ growth peak period), August (fruit harvest stage) and October (dormancy stage), respectively from 2006 to 2008. Nine cores (2 cm in diameter and $40 \mathrm{~cm}$ in length) of soil were taken under the tree canopy in a diagonal transect pattern, using a soil auger from each sub-plot. Collected soil samples were mixed thoroughly to form a composite sample and reduce the variance associated with aggregated spatial patterns of nematodes in soil (Barker \& Campbell, 1981). Thus, a total of 24 soil samples (2 orchards $\times 3$ sub-plots $\times 4$ times) were collected each year. Soil samples were sieved $(2 \mathrm{~mm})$ and transferred to individual plastic bags, immediately transferred to a cold room with a temperature of $4{ }^{\circ} \mathrm{C}$, and then processed within a week.

Nematodes were extracted from a $100 \mathrm{~g}$ (fresh weight) soil sample, using a washing-sieving sugar flotation and centrifugation procedure (Courtney et al., 1955). Extracted nematodes were killed at $60{ }^{\circ} \mathrm{C}$ and fixed in $5 \%$ Formalin acetic acid (Griffiths et al., 1990). Soil moisture content was determined by oven drying.

Nematodes were identified to genus using a Leica microscope (400x) using diagnostic keys (Goodey \& Goodey, 1963; Yin, 1998; Xie, 2005). All nematodes were assigned to one of four trophic groups: bacterivores, fungivores, omnivores/predators and plant-
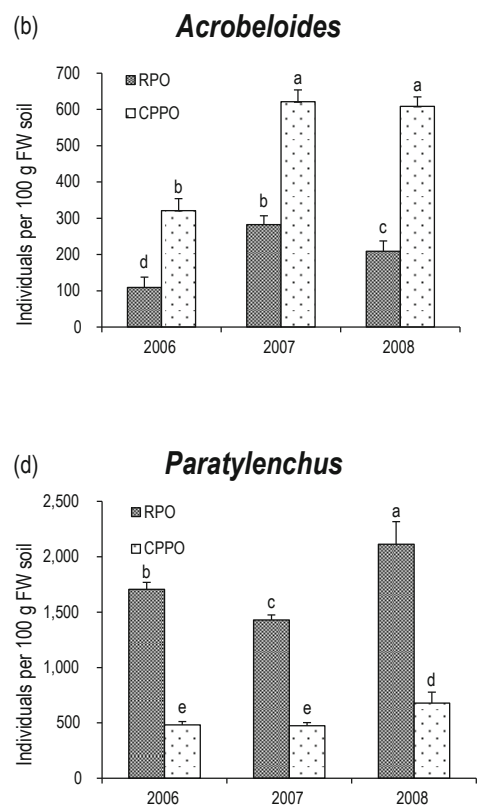

Fig. 1. The absolute abundance of nematode populations in RPO and CPPO averaged over the peach growing season from 2006 to 2008 (bars=mean; error bars=standard deviation). (a) Eucephalobus; (b) Acrobeloides; (c) Aphelenchoides; (d) Paratylenchus. Different letters indicate significant differences $(p<0.05$; two-way ANOVA, post-hoc Duncan) 
Table 1. List of families, genera, guilds and dominance of soil nematodes found from replant peach orchard (RPO) and continuous-planting peach orchard (CPPO) averaged over the peach growing season from 2006 to 2008

\begin{tabular}{|c|c|c|c|c|c|c|c|c|}
\hline \multirow[t]{2}{*}{ Family } & \multirow[t]{2}{*}{ Genera } & \multirow[t]{2}{*}{ Guild a } & \multicolumn{2}{|c|}{$\begin{array}{c}\text { Dominance } \\
(2006)\end{array}$} & \multicolumn{2}{|c|}{$\begin{array}{c}\text { Dominance } \\
(2007)\end{array}$} & \multicolumn{2}{|c|}{$\begin{array}{l}\text { Dominance } \\
\text { (2008) }\end{array}$} \\
\hline & & & RPO & CPPO & RPO & CPPO & RPO & CPPO \\
\hline Diplogasteridae & Diploscapter & $\mathrm{Ba}_{1}$ & $+b$ & + & +++ & ++ & + & + \\
\hline \multirow[t]{2}{*}{ Rhabditidae } & Protorhabditis & $\mathrm{Ba}_{1}$ & - & - & - & - & + & +++ \\
\hline & Rhabditis & $\mathrm{Ba}_{1}$ & +++ & +++++ & +++ & ++++ & ++++ & +++++ \\
\hline \multirow[t]{5}{*}{ Cephalobidae } & Acrobeles & $\mathrm{Ba}_{2}$ & + & + & + & + & - & - \\
\hline & Acrobeloides & $\mathrm{Ba}_{2}$ & +++ & +++++ & ++++ & +++++ & ++++ & +++++ \\
\hline & Cephalobus & $\mathrm{Ba}_{2}$ & - & - & - & + & +++ & ++++ \\
\hline & Cervidellus & $\mathrm{Ba}_{2}$ & - & + & + & + & - & - \\
\hline & Eucephalobus & $\mathrm{Ba}_{2}$ & ++ & +++ & +++ & +++++ & +++ & ++++ \\
\hline Monhysteridae & Monhystera & $\mathrm{Ba}_{2}$ & + & + & + & - & + & - \\
\hline \multirow[t]{2}{*}{ Plectidae } & Plectus & $\mathrm{Ba}_{2}$ & + & + & + & + & - & + \\
\hline & Wilsonema & $\mathrm{Ba}_{2}$ & + & + & + & + & + & + \\
\hline Prismatolaimidae & Prismatolainus & $\mathrm{Ba}_{3}$ & ++ & +++ & + & +++ & ++ & ++ \\
\hline Alaimdae & Alaimus & $\mathrm{Ba}_{4}$ & + & + & - & - & - & - \\
\hline Aphelenchoididae & Aphelenchoides & $\mathrm{Fu}_{2}$ & ++ & ++ & +++ & ++++ & +++ & ++++ \\
\hline Aphelenchidae & Aphelenchus & $\mathrm{Fu}_{2}$ & +++ & + & +++++ & ++++ & + & +++ \\
\hline Chromadoridae & Chromadorita & $\mathrm{PO}_{3}$ & + & + & + & - & - & - \\
\hline \multirow[t]{3}{*}{ Dorylaimidae } & Dorylaimus & $\mathrm{PO}_{4}$ & + & + & + & +++ & ++ & + \\
\hline & Eudorylaimus & $\mathrm{PO}_{4}$ & + & + & - & - & - & - \\
\hline & Mesodorylaimus & $\mathrm{PO}_{4}$ & + & + & - & - & - & - \\
\hline Criconematidae & Mesocriconemoides & $\mathrm{PF}_{3}$ & + & + & - & - & - & - \\
\hline \multirow[t]{3}{*}{ Hoplolaimidae } & Helicotylenchus & $\mathrm{PF}_{3}$ & + & + & - & - & - & - \\
\hline & Hoplolaimus & $\mathrm{PF}_{3}$ & + & + & - & - & + & + \\
\hline & Rotylenchus & $\mathrm{PF}_{3}$ & +++ & +++ & - & - & - & - \\
\hline Paratylenchidae & Paratylenchus & $\mathrm{PF}_{2}$ & +++++ & +++++ & +++++ & +++++ & +++++ & +++++ \\
\hline Pratylenchidae & Pratylenchus & $\mathrm{PF}_{3}$ & + & + & - & - & + & - \\
\hline \multirow[t]{3}{*}{ Tylenchidae } & Filenchus & $\mathrm{PF}_{2}$ & + & ++ & - & - & - & - \\
\hline & Psilenchus & $\mathrm{PF}_{2}$ & + & + & - & - & - & + \\
\hline & Tylenchus & $\mathrm{PF}_{2}$ & + & ++ & +++ & ++ & ++ & +++ \\
\hline Tylenchorhynchidae & Tylenchorhychus & $\mathrm{PF}_{3}$ & + & + & + & - & - & - \\
\hline Longidoridae & Longidorus & $\mathrm{PF}_{5}$ & + & + & - & - & - & - \\
\hline
\end{tabular}

feeding nematode (Yeates et al., 1993). Nematode genera were also assigned "c-p" values of 1-5, corresponding to their positions along the colonizer-persister continuum of their life-history (Bongers, 1990; Ferris et al., 1999; Ferris \& Matute, 2003).

\section{Ecological indices}

Nematode density was expressed as individuals per $100 \mathrm{~g}$ dry soil (Wu et al., 2008), and nematode taxa were assigned to trophic groups and functional guilds. We also calculated the Genus dominance (Ig) (Simpson, 1949), Trophic diversity index (TD) (Heip et al., 1988), Shannon-Weaver diversity index $\left(H^{\prime}\right)$ (Shannon \& Weaver, 1949), Plant parasite index (PPI) (Bongers, 1990; Freck- man \& Ettema, 1993), as well as Nematode channel ratio (NCR), Channel index $(C l)$, Enrichment index $(E I)$ and Structure index $(S I)$ (Ferris et al., 2001) which were used to assess soil food web status (Yeates, 2003).

\section{Data analysis}

For each orchard, the data in this paper is the grand mean value from the samples of each year ( 3 sub-plots $\times 4$ sampling times per year, 12 samples) with standard deviations. Data was examined by two-way ANOVA followed by Duncan's multiple range tests using the SPSS statistical software Version 17.0. Columns which are designed by the same letter did not differ significantly $(P=0.05)$. 
RPO -2006

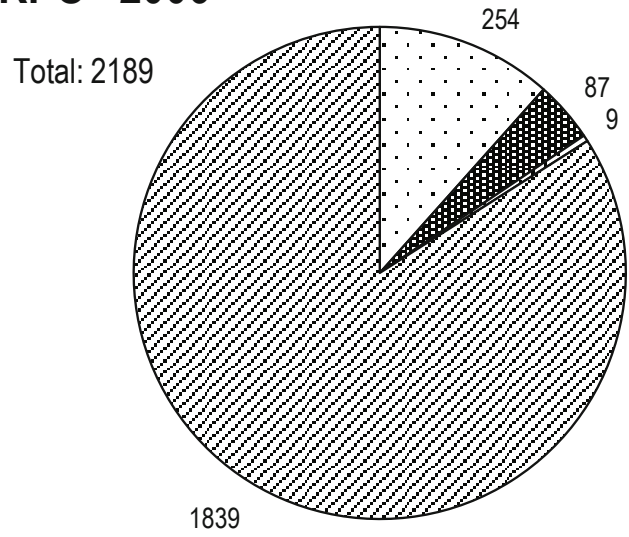

\section{RPO -2007}

Total: 2221

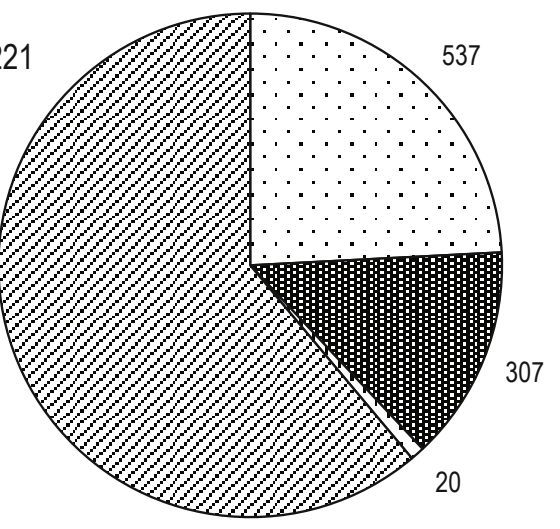

\section{RPO -2008}

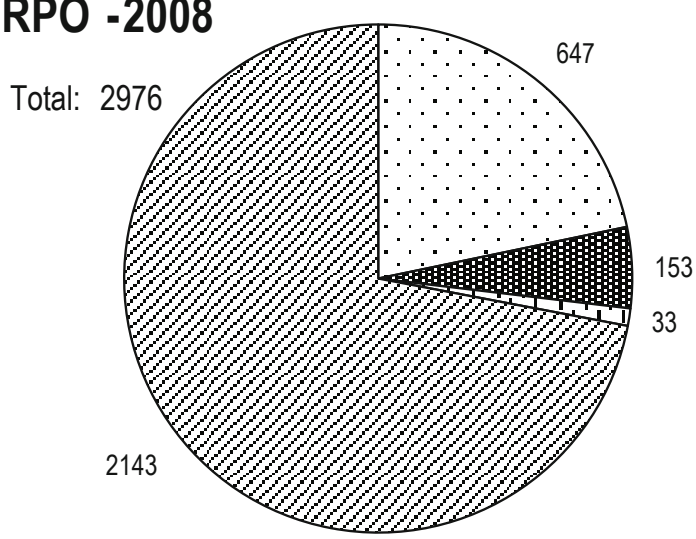
$\square$ Bacterivores
Fungivores
口 Omniovores/Predatores

\section{CPPO -2006}

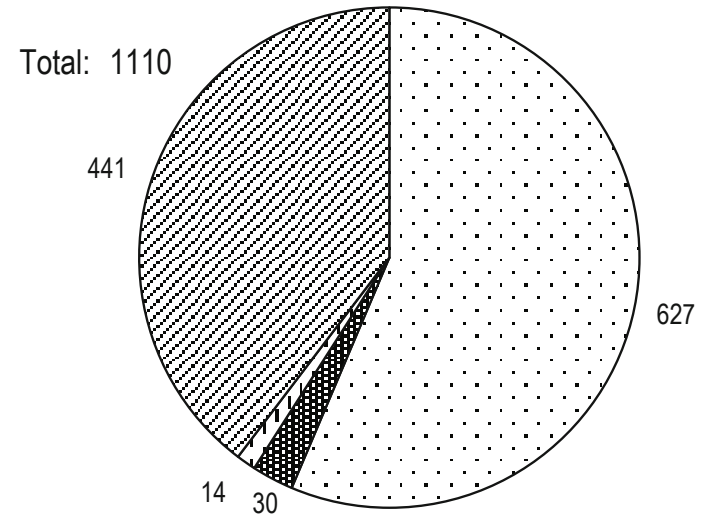

\section{CPPO -2007}

Total: 1976

\section{6}

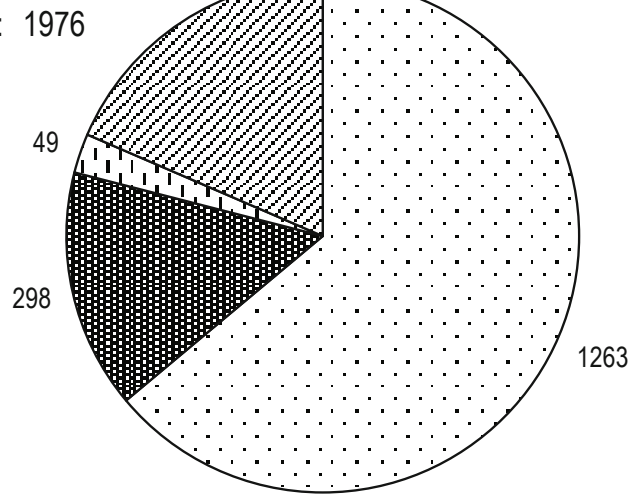

\section{CPPO -2008}

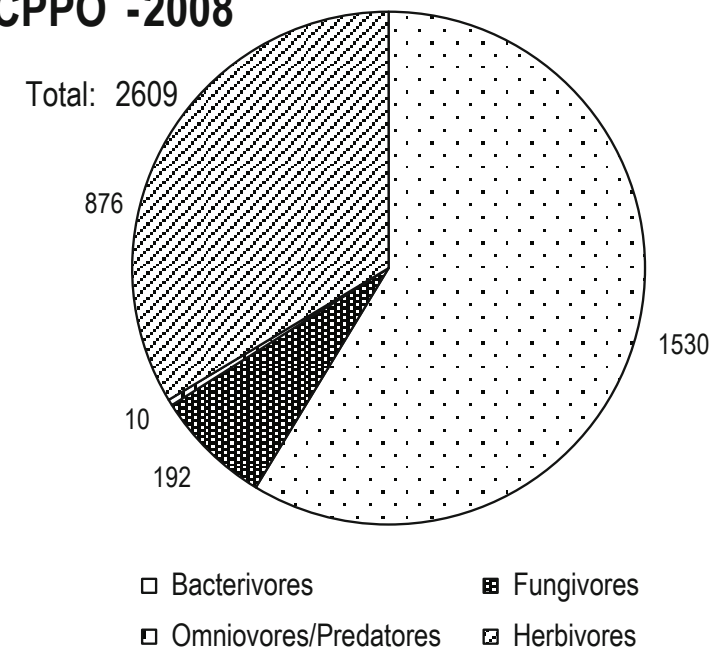

Fig. 2. The absolute abundance of four nematodes trophic groups in RPO and CPPO averaged over the peach growing season from 2006 to 2008 


\section{Results}

\section{Nematode community structure}

A total of thirty genera of nematodes, representing eighteen families were identified in samples from RPO and CPPO ecosystems (Table 1). Two eudominant genera (RA>10\%) were found in the RPO: Aphelenchus, Paratylenchus, while four eudominant genera were isolated from the CPPO: Rhabditis, Acrobeloides, Eucephalobus and Paratylenchus. Three genera (Rhabditis, Aphelenchus, Aphelenchoides) and three genera (Cephalobus, Eucephalobus, Aphelenchoides) were dominant in CPPO in 2007 and 2008, respectively. Paratylenchus was eudominant in both RPO and CPPO, whereas Acrobeloides was only eudominant in CPPO throughout the study.

The absolute abundance of Eucephalobus and Acrobeloides were higher and their populations increased faster in the CPPO than in RPO, whereas the number of Paratylenchus in RPO was greater than that in CPPO throughout the experiment. Generally the number of Aphelenchoides increased steadily, even faster in the CPPO ecosystem from 2006 to 2008 (Fig. 1).

\section{Nematode trophic groups}

Thirteen bacterivores, two fungivores, four predators/omnivores and eleven plant feeding nematodes were found in this study (Table 1). The total number of nematodes collected from the RPO site was significantly greater than that of CPPO site in all the three years. Plant feeding nematodes comprised the most dominant trophic group at the RPO site; with 1357 to 2143 individuals per $100 \mathrm{~g}$ fresh soil from 2006 to 2008. The most dominant trophic group of CPPO was the bacterivores, and the nematode abundance ranged from 627 to 1530 individuals per $100 \mathrm{~g}$ fresh soil during the study period. In both the RPO and CPPO sites, the total number of bacterivorous nematodes doubled from 2006 to 2007 , followed by a slight increase in 2008. Fungivorous nematodes in both sites increased significantly from 2006 to 2007, but decreased by half in 2008. The absolute abundance of plant feeding nematodes in RPO was significantly greater than that of the CPPO throughout the experiment. In each study year, the numbers of total nematodes and bacterivorous nematodes were greater in the CPPO than those in the RPO (Fig. 2).

\section{Nematode diversity indices}

The index values of $/ g$ and PPI from RPO were found to be significantly greater than those in the CPPO $(P<0.05)$, whereas values of TD and $H^{\prime}$ ' in the RPO were significantly lower than those ones in the CPPO, except for similar values of TD in 2007.

\section{Nematode functional indices}

Indices of $\mathrm{NCR}, \mathrm{Cl}, \mathrm{El}, \mathrm{Sl}$ and the faunal profile were used to evaluate the soil food web. Both $N C R$ and $C /$ values fluctuated slightly across all samples during the 3 years, and NCR values did differ between the two ecosystems. Moreover, the mean values of the NCR in CPPO were higher than those in RPO, while $\mathrm{Cl}$ values in RPO were nearly two times as high as ones in CPPO all through the study period (Fig. 3).

The soil food webs among the peach ecosystems were plotted along their respective SI and El trajectories in Fig. 4. The nema- tode assemblages along the gradient mostly did map into the quadrant A, only for CPPO in 2008, which did into the quadrant $D$. Besides, both $E I$ and $S /$ values fluctuated slightly across all samples during this period, and RPO possessed a little higher El values than CPPO accordingly during the three years.

\section{Discussion}

In this study, the genus composition of soil nematodes was similar between RPO and CPPO due to the same plant habitat and same practical management. Plant feeding and bacterivorous nematodes had higher abundance than others, whereas predatory/ omnivorous nematodes were the least group; these results were consistent with previous findings in agricultural soils (Wasilewska, 1979). Moreover, in bacterial-feeding nematodes, the $c p-2$ group made up a higher proportion than the $\mathrm{cp}-1$ group, and increased more during this study in both ecosystems. These results are consistent with those of Yeates et al. (2002), which report that the population of Cephalobus spp. (cp-2) was greater than that of Rhabditis spp. or Pristionchus spp. (cp-1) in undisturbed soils at various soil moisture tensions.

Compared with 2006, the increased population of fungivores in both sites over the next two years indicated that activity and biomass of fungi are promoted with the increase of planting time, although there was a slight fluctuation. This was probably due to chemical fertilizer application, such as ammonium nitrate and urea, which could increase the microfungal population, both in the rhizosphere and non-rhizosphere regions (Mishra, 1979).

The number of soil nematodes and the abundance of trophic groups were different in the two ecosystems with plant feeding nematodes dominant in RPO, and bacterivorous nematodes dominated in CPPO. One hypothesis for higher rate of plant feeding nematodes in RPO concerns the old root residues which couldn't be cleared out totally during replanting. Some studies found that plant feeding nematodes could increase with time during succession in pathogen loads (Van der Putten et al., 1993). In any case, they can be important for soil health feedbacks to manage peach orchards in practices and can be expected to play a key role in environmental conditions of orchard.

Changes in the occurrence and abundance of different trophic groups of nematodes are often associated with changes in crop host and soil management practices, and may reflect changes in the soil food web structure (Nahar et al., 2006). In our experimental plots, Paratylenchus was the most dominant genus of plant feeding nematode in both RPO and CPPO, suggesting peach is a good host of Paratylenchus. Askary et al. (2012) reported that Paratylenchus nematodes feed on plant roots ectoparasitically, which cause necrosis and galls on the roots, thus stunt plant growth. Although no histological or pathological symptoms caused by the Paratylenchus could be detected, higher numbers of Paratylenchus could reduce the growth of apple and apricot (Askary et al., 2012). Therefore, our results suggest that the increasing plant feeding nematodes could attribute to peach replant problem from the point of soil nematode action, here mainly by the increased number of Paratylenchus.

$T D$ describes the diversity of functional groups within the nematode populations, and $I g$ as well as $H$ ' diversity index may be used inter- 
(a)

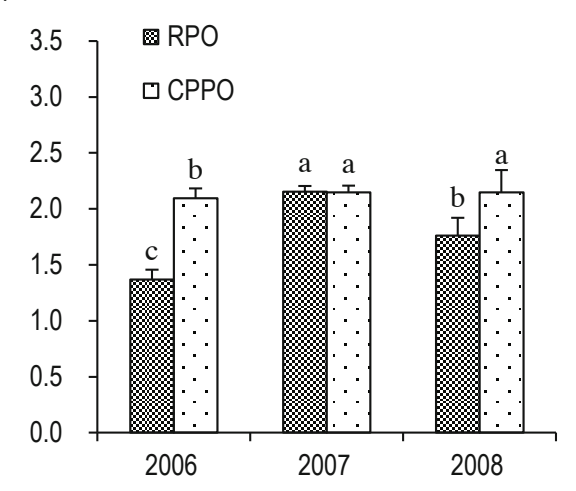

(c)

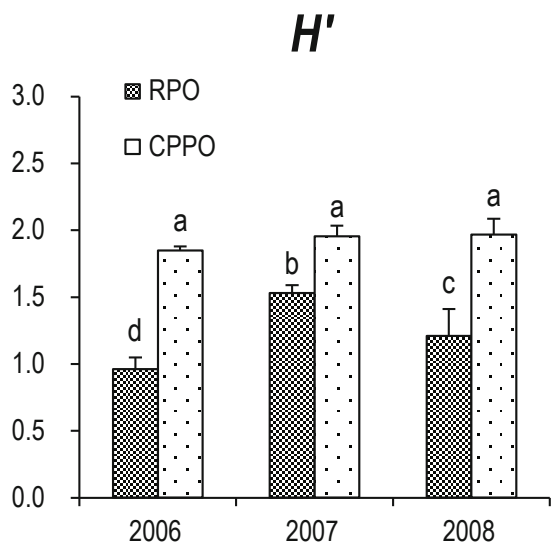

(e)

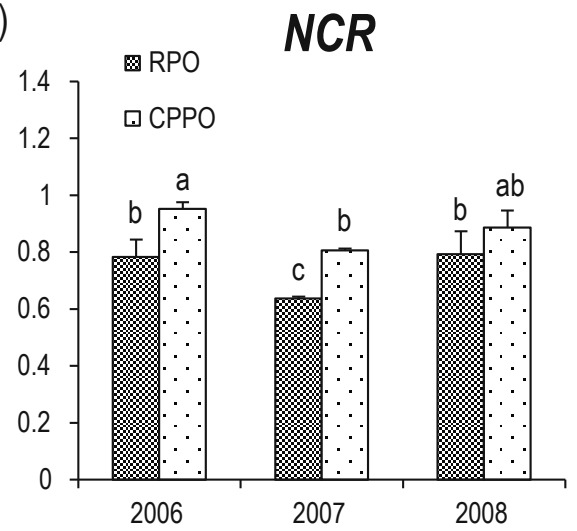

(b)

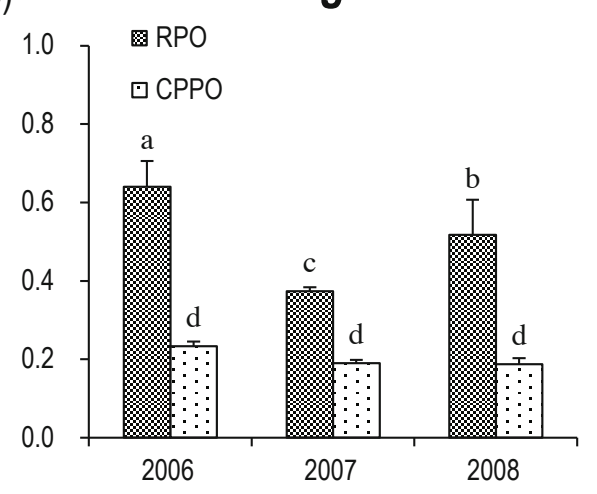

(d)

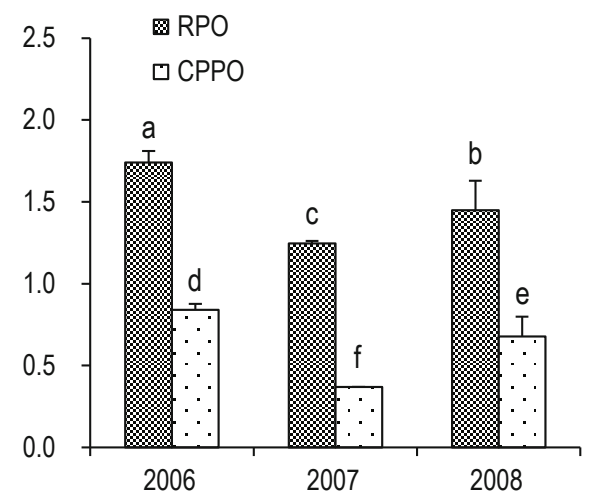

(f)

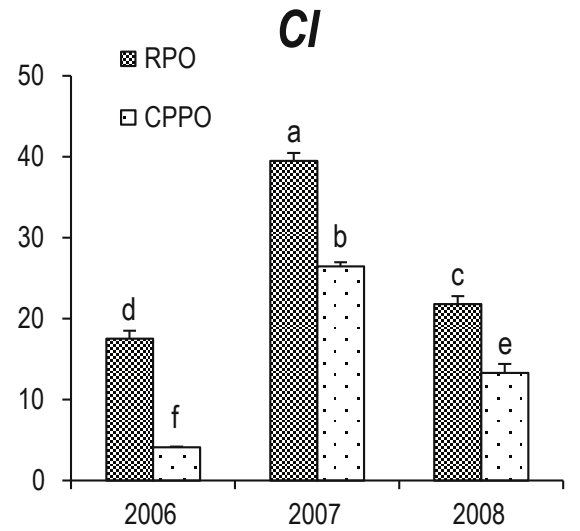

Fig. 3. Ecological indices of nematode communities in RPO and CPPO averaged over the peach growing season from 2006 to 2008 (bars=mean; error bars=standard deviation). (a) Trophic diversity; (b) Genus dominance; (c) Shannon-weaver diversity; (d) Plant parasite index; (e) Nematode channel ratio; (f) Channel index. Means within the same index followed by the same letters are not significantly different $(p<0.05$; two-way ANOVA, post-hoc Duncan)

changeably to give the distribution of species abundance (Shannon \& Weaver, 1949; Simpson, 1949; Porazinska et al., 1999), despite the value scale differences. In detail, Ig weights common taxa, while $H^{\prime}$ is sensitive to rare taxa and can be used to assess nematode diversity in continuous cropping systems (Shannon \& Weaver, 1949; Simpson, 1949; Neher, 2001). In the present study, TD, $H^{\prime}$ and $/ g$ values reflected the higher biodiversity in CPPO, which suggests better ecological conditions in the ecosystems, with greater biodi- versity and better distribution of species abundance and rare species. However, the slight increase of diversity index $H^{\prime}$ of nematode fauna in both ecosystems with increasing of continuous cropping time reflects increases in specific plant-feeding nematodes associated with peach trees. $P P I$ is an ecosystem parameter based on life history characteristics of plant feeding nematodes codes as c-p values (Bongers, 1990). In our 3-year study, PPI values in RPO were significantly higher than ones in CPPO, which slightly decreased 


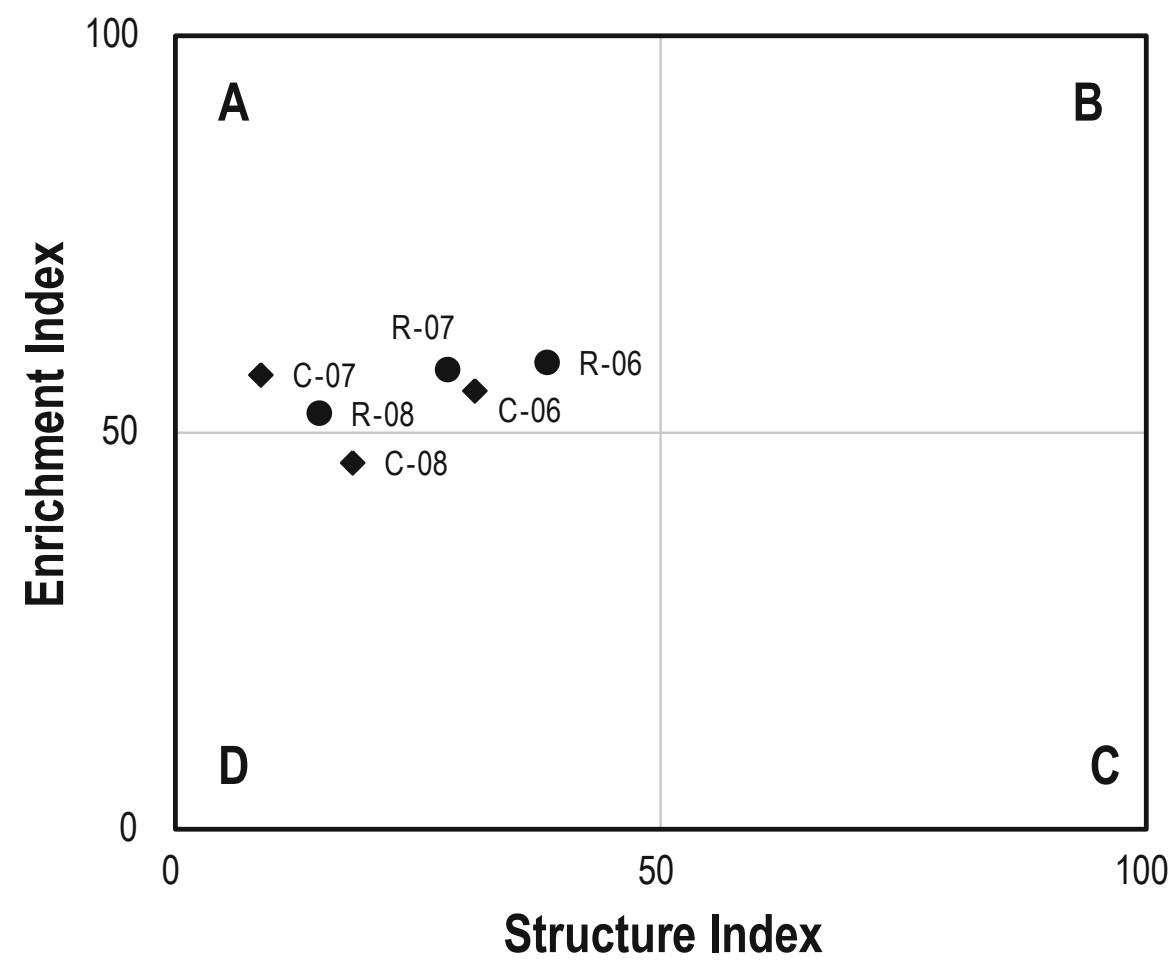

Fig. 4. Faunal profiles representing the structure and enrichment conditions of the soil food web of RPO and CPPO averaged over the peach growing season from 2006 to 2008. R-06 stands for replant peach orchard in 2006; R-07 stands for replant peach orchard in 2007; R-08 stands for replant peach orchard in 2008; C-06 stands for continuous-planting peach in 2006; C-07 stands for continuous-planting peach in 2007; C-08 stands for continuous-planting peach in 2008

with time. Previous studies have shown that plant feeding nematodes decreased with time, possibly related to root systems (Korthals et al., 2001) and PPI decreased with decreasing nutritional level of host plants (Bongers et al., 1997).

$N C R$, with variation between 1 (bacterial feeding nematode dominance) and 0 (fungi feeding nematode dominance), indicated that there was a higher proportion of bacterivorous nematodes than fungivorous nematodes in both ecosystems; and $\mathrm{Cl}$ indicates the predominant decomposition pathways (Ferris et al., 2001; Ruess, 2003). Combined with $\mathrm{Cl}$ related to soil properties, the higher NCR values suggest that a bacterial-decomposer pathway dominated in the two ecosystems.

$S I$ (structure index) and $E I$ (enrichment index) were derived from weighted faunal analysis. $S /$ is a measure of the number of trophic layers and potential for regulation of opportunists; El assesses food-web responses to available resources (Ferris et al., 2001). Meanwhile, nematode faunal analysis provides a powerful tool for diagnosis of the complexity and status of soil food web (Wardle et al., 1995; Ritz \& Trudgill, 1999). In RPO and CPPO ecosystems of present study, the ecological function indices with no discernible pattern reflected the similar disturbance of cultivation to soil environment during the 3 years periods. Despite the small amount variance, they provide insight into soil environmental conditions and ecosystem services based on nematode function and trophic groups (Ferris et al., 2001). Quadrant A providing an indication of high disturbance, $\mathrm{N}$-enriched, bacterial decomposition channels and low $\mathrm{C}$ : $\mathrm{N}$ ratio of the soil web. In the both peach ecosystems, there were higher $E /$ values $(E \mid>50)$, and these data, supported by other studies on agricultural food webs with higher El (Ferris et al., 2001; Ferris \& Bongers, 2006; Leroy et al., 2009), indicated the available resources were enrichment, with higher soil fertility level and better nutrient availability, etc.

$S /$ represents time course progressions in the structure of the soil food web, which is primarily evaluated by omnivores and predators populations. Omnivorous and predatory nematodes are sensitive to disturbance and stress (Bongers \& Bongers, 1998; Ferris et al., 2001). No significant differences were observed on the SI values between the two ecosystems, due to the similar practical management, with low S/ values in the repeated tillage and other disturbed arable agroecosystems (Ferris et al., 2001; Berkelmans et al., 2003; Ferris \& Matute, 2003). In addition, the action of replant peach tree caused some interference with the food web, but the disturbed effects began to get released in 2008; whereas the disturbed condition of the CPPO food web kept getting worse through the three years.

\section{Conclusions}

Overall, nematode community composition, as well as nematode trophic group, was not characterized by RPO or CPPO, but nematode density of dominant groups were different. In addition to higher PPI values in RPO, the increasing plant feeding nematodes, mainly by Paratylenchus spp., could be another main factor for replant diseases in part to the action of soil nematode. With higher $T D, H^{\prime}$ and Ig values, CPPO possessed a better ecological condition, because higher biodiversity indicates better nutrition availabil- 
ity and quicker food responses of microorganism.

Despite no significant differences in weighted nematode faunal profile analysis, nematode ecological and function indices are potentially important tools as an assessment of soil functioning and conditions in peach orchard, and it may be wise to assess and interpret the food web and environmental condition based on these tools for soil resource managers, diagnostic purposes and management decisions.

\section{Acknowledgments}

We thank Dr. Howard Ferris from University of California for suggestion and helping with understanding data analysis. The study was supported by China Special Fund for Forest-scientific Research in the Public Interest (NO. 201004037) and National Key Technology R \& D Program (NO. 2014BAD16B07).

\section{References}

Askary, T. H., Waliullah, M. I. S., GuptA, S. (2012): Population fluctuation of plant parasitic nematodes associated with pome, stone and nut fruit nurseries. Annu. Plant Prot. Sci., 20: 265 - 267

Barker, K. R., Campbell, C. L. (1981): Sampling nematode populations. In: Zuckerman, BM, Rhode RA, editor. Plant Parasitic Nematodes. New York, Academic Press, pp. 451 - 471

Berkelmans, R., Ferris H., Tenuta, M., Bruggen, A. H. C. (2003): Effects of long-term crop management on nematode trophic levels other than plant feeders disappear after 1 year of disruptive soil management. Appl. Soil Ecol., 23: 223 - 235. DOI: 10.1016/ S0929-1393(03)00047-7

Bongers, T. A. (1990): The maturity index: an ecological measure of environmental disturbance based on nematode species composition. Oecologia, 83: 14 - 19. DOI: 10.1007/BF00324627

Bongers, T., Van Der Meulen, H. Korthals, G. (1997): Inverse relationship between the nematode maturity index and plant parasite index under enriched nutrient conditions. Appl. Soil Ecol., 6: 195 - 199. DOI: 10.1016/S0929-1393(96)00136-9

Bongers, T., Bongers, M. (1998): Functional diversity of nematodes. Appl. Soil Ecol., 10: 239 - 251. DOI: 10.1016/S09291393(98)00123-1

Bongers, T, FERRIS, H. (1999): Nematode community structure as a bioindicator in environmental monitoring. Heredity, 81: $164-173$. DOI: 10.1016/S0169-5347(98)01583-3

Courtney, W. D., Polley, D., Miller, V. L. (1955): TAF, an improved fixative in nematode technique. Plant Dis. Rep., 39: 570 - 571

Derrick, K. S., Timmer, L. W. (2000): Citrus blight and other diseases of recalcitrant etiology. Annu. Rev. Phytopathol., 38: 181 - 205. DOI: 10.1146/annurev.phyto.38.1.181

Ferris, H., Bongers, T., Goede, R. G. M. (1999): Nematode faunal indicators of soil food web condition. J. Nematol., 31: 534 - 535

Ferris, H, Bongers, T, Goede, R. G. M. (2001): A framework for soil food web diagnostics: extension of the nematode faunal analysis concept. Appl. Soil Ecol., 18: 13 - 29. DOI: 10.1016/S09291393(01)00152-4

FerrIs, H., Bongers, T. (2006): Nematode indicators of organic enrichment. J. Nematol., 38: 3
Ferris, H, Matute, M. M. (2003): Structural and functional succession in the nematode fauna of a soil food web. Appl. Soil Ecol., 23: 93 - 110. DOI: 10.1016/S0929-1393(03)00044-1

Freckman, D. W., Ettema, C. H. (1993): Assessing nematode communities in agroecosystems of varying human intervention. Agr. Ecosyst. Environ., 45: 239 - 261. DOI: 10.1016/01678809(93)90074-Y

Goodey, T, Goodey, J. (1963): Soil and freshwater nematodes. London: Methue.

Griffiths, B. S., Boag B., Nellson, R., Palmer, L. (1990): The use of colloidal silica to extract nematodes from small samples of soil and sediment. Nematologica, 36: 465 - 473. DOI: 10.1163/002925990X00437

Heip, C., Herman. M, Soetaert. K. (1988): Data processing, evaluation, and analysis. Washington DC, Smithsonian Institution Press. IUSS WorkIng Group WRB (2006): World reference base for soil resources 2006. 2nd edition. World Soil Resources Reports No. 103. FAO, Rome. ISBN 92-5-105511-4 Retrieved from http://www. fao.org/ag/agl/agll/wrb/doc/wrb2006final.pdf

KocH, L. (1955): The peach replant problem in Ontario: I. symptomatology and distribution. Can. J. Bot., 33: $450-460$.

Korthals, G. W., Smilauer, P., Dijk C. V., Putten W. H. V. (2001): Linking above-and below-ground biodiversity: abundance and trophic complexity in soil as a response to experimental plant communities on abandoned arable land. Funct. Ecol., 15: 506 - 514. DOI: 10.1046/j.0269-8463.2001.00551.x

Leroy, B. L. M, Sutter, N. D., Ferris, H., Moens, M., Reheul, D. (2009): Short-term nematode population dynamics as influenced by the quality of exogenous organic matter. Nematology, 11: 23 38. DOI: $10.1163 / 156854108 \times 398381$

MISHRA, R. R. (1979): Effect of certain chemical fertilizers on the rhizosphere mycoflora of Oryza sativa I. Mycopathologia, 44: 167 - 176. DOI: 10.1007/BF02051885

Nahar, M. S., Grewal, P. S., Miller, S. A., Stinner, D., Stinner, B. R., KleINHenz, M. D., Wszelakı, A., Doohan, D. (2006): Differential effects of raw and composted manure on nematode community, and its indicative value for soil microbial, physical and chemical properties. Appl. Soil Ecol., 34: 140 - 151. DOI: 10.1016/j.apsoil.2006.03.011 Neher, D. (2001): Role of nematodes in soil health and their use as indicators. J. Nematol., 33: 161.

NiCKLE, W. R. (1984): Plant and insect nematode. New York, Marcel Dekker, Inc.

Porazinska, D. L., Duncan, L. W., McSorley, R., Graham, J. H. (1999): Nematode communities as indicators of status and processes of a soil ecosystem influenced by agricultural management practices. Appl. Soil Ecol., 13: 69 - 86. DOI: 10.1016/S09291393(99)00018-9

RITZ, K. D., TRUDGILL, D. L. (1999): Utility of nematode community analysis as an integrated measure of the functional state of soils: perspectives and challenges. Plant Soil, 212: 1 - 11. DOI: 10.1023/A: 1004673027625

RuESS, L. (2003): Nematode soil faunal analysis of decomposition pathways in different ecosystems. Nematology, 5: 179 - 181. DOI: 10.1163/156854103767139662

Shannon, C. E, WeAver, W. (1949): The mathematical theory of communication. Urbana, Univ Illinois Press. 
Simpson, E. H. (1949): Measurement of diversity. Nature, 163: 688. ThORNTON, C. M., MATLACK, G. R. (2002): Long-term disturbance effects in the nematode communities of south Mississippi woodlands. J. Nematol., 34: $88-97$

Van der Putten, W. H., Van DiJk, C., Peters, B. A. M. (1993): Plantspecific soil-borne diseases contribute to succession in foredune vegetation. Nature, 362: 53 - 56. DOI: 10.1038/362053a0

Wardle, D. A., Yeates, G. W., Watson, R. N., Nicholson, K. S. (1995): The detritus food-web and the diversity of soil fauna as indicators of disturbance regimes in agro-ecosystems. Plant Soil, 170: 35 - 43. DOI: 10.1007/BF02183053

WASILEWSKA, L. (1994): The effect of age of meadows on succession and diversity in soil nematode communities. Pedobiologia, 38: 1 - 11 Wu, H. Y., LI, X. X., Sh, L. B., Wang, Z. H., MA, F. Y. (2008): Distribution of nematodes in wetland soils with different distance from the Bohai sea. Plant Soil Environ., 54: 359 - 366.
XIE H. (2005): Taxonomy of Plant Nematodes, 2nd ed. Beijing: China Higher Education Press.

Yeates, G. W., Bongers, T., Goede, R. D. M., Freckman, D. W., GEORGIEVA, S. S. (1993): Feeding habits in soil nematode families and genera-an outline for soil ecologists. J. Nematol., 25: 315.

Yeates, G. W., Dando, J., Shepherd, T. G. (2002): Pressure plate studies to determine how moisture affects access of bacterialfeeding nematodes to food in soil. Eur. J. Soil Sci., 53: $355-365$. DOI: 10.1046/j.1365-2389.2002.00466.x

YeAtes, G. W. (2003): Nematodes as soil indicators: functional and biodiversity aspects. Biol. Fert. Soils, 37: 199 - 210. DOI: 10.1007/ s00374-003-0586-5

YIN, W. (1998): Pictorial Keys of Soil Animals in China. Beijing, Science Press. 